\title{
Effect of Water and Glycerol in Deoxygenation of Coconut Oil over Bimetallic NiCo/SAPO-11 Nanocatalyst under $\mathrm{N}_{2}$ Atmosphere
}

\author{
Rungnapa Kaewmeesri ${ }^{1,2}{ }^{(\mathbb{D}}$, Jeeranan Nonkumwong ${ }^{2} \mathbb{(}$, Thongthai Witoon ${ }^{3,4}$, \\ Navadol Laosiripojana ${ }^{1}$ and Kajornsak Faungnawakij ${ }^{2,4, *(D)}$ \\ 1 The Joint Graduate School of Energy and Environment (JGSEE), King Mongkut's University of Technology \\ Thonburi, Bangkok 10140, Thailand; rungnapa@nanotec.or.th (R.K.); navadol@jgsee.kmutt.ac.th (N.L.) \\ 2 National Nanotechnology Center (NANOTEC), National Science and Technology Development \\ Agency (NSTDA), Pathum Thani 12120, Thailand; jeeranan.non@nanotec.or.th \\ 3 Center of Excellence on Petrochemical and Materials Technology, Department of Chemical Engineering, \\ Kasetsart University, Bangkok 10900, Thailand; fengttwi@ku.ac.th \\ 4 Research Network of NANOTEC-KU on NanoCatalysts and NanoMaterials for Sustainable Energy and \\ Environment, Kasetsart University, Bangkok 10900, Thailand \\ * Correspondence: kajornsak@nanotec.or.th; Tel.: +66-2-564-7100 (ext. 6638); Fax: +66-2-564-6981
}

Received: 18 November 2020; Accepted: 14 December 2020; Published: 18 December 2020

\begin{abstract}
The catalytic deoxygenation of coconut oil was performed in a continuous-flow reactor over bimetallic NiCo/silicoaluminophosphate-11 (SAPO-11) nanocatalysts for hydrocarbon fuel production. The conversion and product distribution were investigated over NiCo/SAPO-11 with different applied co-reactants, i.e., water $\left(\mathrm{H}_{2} \mathrm{O}\right)$ or glycerol solution, performed under nitrogen $\left(\mathrm{N}_{2}\right)$ atmosphere. The hydrogen-containing co-reactants were proposed here as in-situ hydrogen sources for the deoxygenation, while the reaction tests under hydrogen $\left(\mathrm{H}_{2}\right)$ atmosphere were also applied as a reference set of experiments. The results showed that applying co-reactants to the reaction enhanced the oil conversion as the following order: $\mathrm{N}_{2}$ (no co-reactant) $<\mathrm{N}_{2}\left(\mathrm{H}_{2} \mathrm{O}\right)<\mathrm{N}_{2}$ (aqueous glycerol) $<\mathrm{H}_{2}$ (reference). The main products formed under the existence of $\mathrm{H}_{2} \mathrm{O}$ or glycerol solution were free fatty acids (FFAs) and their corresponding $\mathrm{C}_{\mathrm{n}-1}$ alkanes. The addition of $\mathrm{H}_{2} \mathrm{O}$ aids the triglyceride breakdown into FFAs, whereas the glycerol acts as hydrogen donor which is favourable to initiate hydrogenolysis of triglycerides, causing higher amount of FFAs than the former case. Consequently, those FFAs can be deoxygenated via decarbonylation/decarboxylation to their corresponding $\mathrm{C}_{\mathrm{n}-1}$ alkanes, showing the promising capability of the $\mathrm{NiCo} / \mathrm{SAPO}-11$ to produce hydrocarbon fuels even in the absence of external $\mathrm{H}_{2}$ source.
\end{abstract}

Keywords: deoxygenation; coconut oil; in-situ hydrogen; nickel-cobalt bimetallic nanoparticles; biorefinery

\section{Introduction}

Hydrotreating is a typical process in the production of petroleum fuels from fossil crude oils using active sulfided catalysts, e.g., supported NiMo, CoMo, and NiW, operated under hydrogen atmosphere [1]. However, in order to secure economic feasibility as well as the environmental sustainability, many studies have been carried out to improve the process by finding new kinds of alternative resources, applying an inert ambient to the process, and/or using non-sulfided catalysts [2-4]. Nowadays, renewable oils, animal fats, and biodiesel from low-grade oils/fats are considered as alternative sources for hydrocarbon fuel production [5-7]. Lately, an upgrading of hydrocarbon fuels, which mostly consists of linear alkanes, to higher fraction of branched alkanes for the use as jet fuel-like 
hydrocarbons has received considerable attention because the demand of fuel for the aviation sectors has been increasing.

Principally, jet fuel-like hydrocarbon is produced from renewable oils through well-known processes where the oxygen in the oil's molecules is removed by hydrodeoxygenation followed by hydro-isomerization/cracking, and distillation as the last step. To this procedure, a huge amount of hydrogen is required. For example, one molecule of triglyceride (TG) in vegetable oil reacts with twelve molecules of hydrogen gas $\left(\mathrm{H}_{2}\right)$ for hydrodeoxygenation (HDO), six molecules of $\mathrm{H}_{2}$ for decarbonylation (DCO), or three molecules of $\mathrm{H}_{2}$ for decarboxylation $\left(\mathrm{DCO}_{2}\right)$ route to form three molecules of alkanes [8,9]. The $\mathrm{H}_{2}$ consumption for the catalytic deoxygenation via those three major pathways is in the order of $\mathrm{HDO}>\mathrm{DCO}>\mathrm{DCO}_{2}$ [10]. Therefore, the $\mathrm{DCO} / \mathrm{DCO}_{2}$ pathway has been more widely studied due mainly to its less hydrogen consumption. Specifically, three molecules of $\mathrm{H}_{2}$ are initially used for breaking a TG molecule into propane and free fatty acids (FFAs). Then, FFAs will further convert to hydrocarbons via $\mathrm{DCO}_{2}$ reaction without the need of hydrogen source. To promote the deoxygenation rate, well-designed non-sulfided catalysts are essential.

Hollak et al. [11] studied the catalytic activity of Pd/C catalyst for HDO of triglycerides (TGs) and FFAs. The results showed that even though the hydrogen produced in-situ from glycerol reforming can help for hydrocarbon product formation, the main products were still long-chain unsaturated hydrocarbons. This could be because the hydrogen production from glycerol using $\mathrm{Pd} / \mathrm{C}$ catalyst was rather low. Similarly, Chiapper et al. [12] found that unsaturated hydrocarbon products were also the most selective in the deoxygenation of coconut oil and palm kernel oil over $\mathrm{PtSnK} / \mathrm{SiO}_{2}$, even though mild hydrogenation treatment was performed to saturate mono- and polyunsaturated bonds in TGs prior to deoxygenation. A comparison of three catalysts, i.e., $1 \mathrm{wt} \% \mathrm{Pt} / \mathrm{C}, 5 \mathrm{wt} \% \mathrm{Pd} / \mathrm{C}$, and $20 \mathrm{wt} \%$ $\mathrm{Ni} / \mathrm{C}$, was studied by Morgan and co-workers [13] for the deoxygenation of TGs (tristearin, triolein, or soybean oil) under $\mathrm{N}_{2}$ atmosphere. The supported non-noble Ni metal was found to provide significantly higher TGs conversion and fraction of $\mathrm{C}_{8}-\mathrm{C}_{17}$ compounds than the noble $\mathrm{Pd}$ and $\mathrm{Pt}$ metals. Miao et al. [14] also attempted to convert palmitic acid through non-noble Ni metal supported on $\mathrm{ZrO}_{2}$ with low-pressure or without external supply of $\mathrm{H}_{2}$ in the presence of water. The conversion of palmitic acid was significantly improved, and the results showed that hydrogenolysis promoted palmitic conversion and DCO occurred as the major reaction. Although non-noble Ni metal can be efficient to drive the reaction under $\mathrm{H}_{2}$ atmosphere, about $20 \mathrm{wt} \%$ of $\mathrm{Ni}$ loading was needed in their research. Apart from the widely used Ni-based catalysts, Co-based catalysts also have been reported providing high yield of hydrocarbons from deoxygenation of TGs (triolein, ceiba oil, and sterculia oil) under inert $\mathrm{N}_{2}$ flow condition via $\mathrm{DCO}_{2}$ pathway [15]. Moreover, it is well-documented that lower acidity of $\mathrm{Co}$ than $\mathrm{Ni}$ may assist lowering of catalyst coking and subsequent deactivation. Thus, Co shows potential to be addressed as an alternative or a component in Ni-based bimetallic catalysts.

The $\mathrm{H}_{2}$ produced from glycerol aqueous-phase reforming (APR) is of interesting to utilize for the in-situ deoxygenation of TG molecules. In 2002, the pioneer work [16] applied glycerol into the system to generate in-situ $\mathrm{H}_{2}$ for the reaction. However, the hydrogen production is always accompanied by several side reactions, such as methanol decomposition, water gas shift reaction, and methanation [17-20]. Therefore, the hydrogen yield is highly related to the performance of the catalysts which actively involves for the $\mathrm{C}-\mathrm{C}, \mathrm{C}-\mathrm{H}$, and $\mathrm{C}-\mathrm{O}$ bonds scission, especially the cleavage of the $\mathrm{C}-\mathrm{H}$ bond. The development of bimetallic catalysts such as $\mathrm{Ni}-\mathrm{Cu}[17,18]$ or Ni-Co [19] is an efficient way to control the selectivity as the second metal can affect metal particle sizes or strengthen metal-support interaction to improve water gas shift reaction or inhibit methanation reaction.

Previously, Zhong and co-worker [21] studied the in-situ hydrogen production from high temperature water with $\mathrm{Ni}$ catalysts. In the system, high temperature water, with weak hydrogen bonds, was oxidized by active reductant metals as following; $\mathrm{M}+\mathrm{H}_{2} \mathrm{O} \rightarrow \mathrm{H}_{2}+\mathrm{M}_{\mathrm{x}} \mathrm{O}_{\mathrm{y}}$. Those results suggested that co-feeding with glycerol and water is clearly proved to be a facile hydrogen source for the deoxygenation of TGs to hydrocarbon fuels $[21,22]$. 
In this work, we studied the deoxygenation of TG to hydrocarbon alkanes via catalytic deoxygenation (under $\mathrm{N}_{2}$ ambient) and in-situ $\mathrm{HDO}$ (by $\mathrm{H}_{2} \mathrm{O}$ or glycerol addition) in comparison with conventional $\mathrm{HDO}$ (under $\mathrm{H}_{2}$ ambient) to yield oxygen-free hydrocarbons. The $\mathrm{NiCo}$ (about $10 \mathrm{wt} \%$ metal loading) supported on commercially available silicoaluminophosphate-11 (SAPO-11) was used as the deoxygenation catalyst. SAPO-11 is a molecular sieve material with 10-ring porous structure that has been extensively utilized due to its stability and potential activity in many catalytic processes $[23,24]$. The catalytic hydro/deoxygenation reactions of medium-chain (mostly $\mathrm{C}_{12}$ ) TGs in coconut oil, without hydrogenation treatment prior to deoxygenation, were examined to describe the reaction pathway via the degree of oxygen removal and product distribution, depending on the variable feed molecules. To the best of our knowledge, it is reported for the first time that SAPO-11-supported $\mathrm{NiCo}$ nanoparticles could directly convert coconut oil to jet fuel-like hydrocarbons with the in-situ hydrogen donors.

\section{Materials and Methods}

\subsection{Materials}

Commercial coconut oils were obtained from local companies in Thailand. Analytical grade glycerol $\left(\mathrm{C}_{3} \mathrm{H}_{8} \mathrm{O}_{3}, 99 \%\right.$ purity) was obtained from Fisher Scientific, Fair Lawn, NJ, USA. Hydrogen gas $\left(\mathrm{H}_{2}, 99.99 \%\right.$ purity) and nitrogen gas $\left(\mathrm{N}_{2}, 99.5 \%\right.$ purity) were obtained from S.I. Technology Co., Ltd., Bangkok, Thailand. SAPO-11 powder, used as the catalyst support, was purchased from ACS Material, Pasadena, CA, USA. Deionized (D.I.) water $\left(18.2 \mathrm{M} \Omega \cdot \mathrm{cm}\right.$, at $\left.25^{\circ} \mathrm{C}\right)$ was produced by water purification machine in laboratory. Hydrocarbon standards $\left(\mathrm{C}_{8}-\mathrm{C}_{18}\right)$ for calibration were purchased from Sigma-Aldrich, Buchs, Switzerland. Analytical reagent grade of nitrate salts of nickel $\left(\mathrm{Ni}\left(\mathrm{NO}_{3}\right)_{2} \cdot 6 \mathrm{H}_{2} \mathrm{O}\right)$ and cobalt $\left(\mathrm{Co}\left(\mathrm{NO}_{3}\right)_{2} \cdot 6 \mathrm{H}_{2} \mathrm{O}\right)$ were purchased from Ajax FineChem, Taren Point, NSW, Australia.

\subsection{Catalyst Preparation}

The catalyst was prepared by co-impregnation technique by dissolving nitrate salts of $\mathrm{Ni}$ and $\mathrm{Co}$ in D.I. water. Then, SAPO-11 powder was further added to obtain $5 \mathrm{wt} \%$ loading of each metal. Mixing as well as drying were employed using a magnetic stirrer hot plate at $85^{\circ} \mathrm{C}$ for $3 \mathrm{~h}$ and transferred to vacuum oven at the same temperature for overnight. The resultant powder was calcined in static air at $500{ }^{\circ} \mathrm{C}$ for $5 \mathrm{~h}$. The final sample was denoted as NiCo/SAPO-11. Before catalytic testing, the catalyst powder was pelleted, sieved into $0.5-1.0 \mathrm{~mm}$. in size.

\subsection{Catalyst Characterization}

Crystalline phase of the prepared catalyst was analysed by X-ray diffraction (XRD) measurement using an X-ray diffractometer (D8 ADVANCE, Bruker, Ltd., Karlsruhe, Germany) with Cu K $\alpha$ radiation (wavelength of $1.5406 \AA$ ). The diffraction angle was scanned from $2 \theta$ of $5^{\circ}$ to $80^{\circ}$, with steps of $0.5^{\circ} / \mathrm{min}$ and counting at $0.02 \mathrm{~s} / \mathrm{step}$. The specific surface area and pore structures of the samples were calculated by the Brunauer-Emmett-Teller (BET) and the density functional theory (DFT)/Barrett-Joyner-Halenda (BJH) methods, respectively, via nitrogen adsorption-desorption technique (Quantachrome Autosorb-iQ3, Boynton Beach, FL, USA). The total pore volume was measured at the relative pressure $(\mathrm{P} / \mathrm{P} 0)$ of 0.98 . Before measurement, the sample of approximately $0.2 \mathrm{~g}$ was outgassed at $120^{\circ} \mathrm{C}$ for $3 \mathrm{~h}$ under helium flow. Total acidity and strength of acid sites of catalyst were evaluated by ammonia $\left(\mathrm{NH}_{3}\right)$-temperature programmed desorption $\left(\mathrm{NH}_{3}\right.$-TPD) carried out using Quantachrome Chemisorption Analyzer ChemStar TPX Series (Boynton Beach, FL, USA). Scanning electron microscopy (SEM) analysis was performed with a S-3400N (Hitachi-Science \& Technology, Berkshire, UK), operated at $5 \mathrm{kV}$. Transmission electron microscopy (TEM) images were acquired by JEOL-JEM-2100Plus instrument (Akishima, Tokyo, Japan) equipped with an energy dispersive X-ray spectrometer (EDS). The TEM machine was operated at an accelerating voltage of 
$200 \mathrm{kV}$. Before measurement, the sample was reduced at $700{ }^{\circ} \mathrm{C}$ in a flow of $\mathrm{H}_{2}$ for $2 \mathrm{~h}$. The obtained powder was grounded then dispersed in ethanol, followed by sonication for $30 \mathrm{~min}$ to make the particle well-dispersed, and dropped onto a gold grid.

\subsection{Catalytic Deoxygenation Testing in Continuous-Flow Fixed-Bed Reactor}

The deoxygenation reaction was operated in a custom-made continuous-flow trickle-bed reactor made of the stainless steel 316, with an external diameter of $1.28 \mathrm{~cm}$, internal diameter of $1 \mathrm{~cm}$, and length of $70 \mathrm{~cm}$. The catalyst bed was located at the middle of the fixed-bed reactor and held in position with quartz wool plugs at uniform temperature position (confirmed by inside thermocouples inserted in the catalyst bed). The reaction in the continuous system consists of a feed tank, a reactor unit, and a gas-liquid product separation unit, as shown in Figure 1. The temperature was controlled by using electrical furnace with two positions of temperature controller. A K-type thermocouple was inserted to contact the catalyst bed for temperature monitoring. The pressure of the reactor was manually controlled by using back pressure regulator (BPG) for two-phase flow. High-performance liquid chromatography (HPLC) pump and mass flow controller (MFC) were used to control the flow rate of liquid and gas feed, respectively.

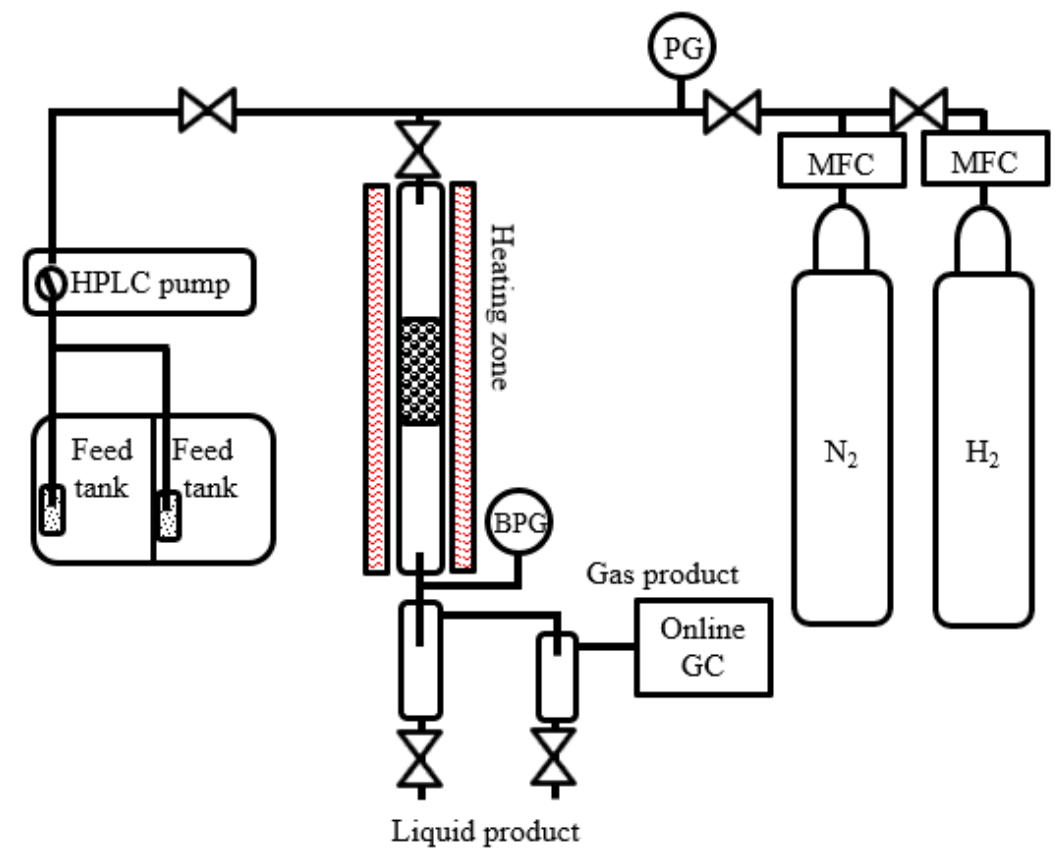

Figure 1. Schematic diagram of continuous-flow reactor system for catalytic testing.

In a typical run, $4 \mathrm{~mL}$ of catalyst was loaded into a reactor and reduced with $50 \mathrm{~cm}^{3} / \mathrm{min}$ of pure $\mathrm{H}_{2}$ at $650{ }^{\circ} \mathrm{C}$ for $2 \mathrm{~h}$. After the catalyst reduction step, the continuous reaction system was immediately flushed with reaction gas $\left(\mathrm{N}_{2}\right.$ or $\left.\mathrm{H}_{2}\right)$ and set up to the desired temperature under pressurized condition. Liquid feeds - coconut oil, water, and glycerol solution-were separately introduced by two-suction line in the HPLC pump.

Four different experimental practices were performed as follows:

Practice \#1 was designed as a reference experiment for the purpose of investigating the catalytic performance on HDO of feed oil over $\mathrm{NiCo} / \mathrm{SAPO}-11$ catalyst. The reaction was performed at $330{ }^{\circ} \mathrm{C}$ under 50 bar of $\mathrm{H}_{2}$ atmosphere, and liquid feed (i.e., coconut oil) was introduced into the reactor with liquid hourly space velocity (LHSV) of $1 \mathrm{~h}^{-1}$.

Practice \#2 aimed to investigate the catalytic performance on the deoxygenation with absent $\mathrm{H}_{2}$. The procedure was similar to that described in practice \#1, except the operating gas which was $\mathrm{N}_{2}$. 
Practice \#3 aimed to investigate the catalytic performance on the coupling deoxygenation of feed oil with in-situ $\mathrm{H}_{2}$ production by glycerol-APR. In short, the feed was introduced into the reactor by two-suction lines in HPLC pump, one for oil feed ( $80 \%$ by vol.) and one for glycerol solution feed ( $20 \%$ by vol.). The glycerol solution of $36 \mathrm{wt} \%$ glycerol in water (140 g of glycerol in $250 \mathrm{~g}$ of water) which was 0.1 mole ratio of glycerol: water) was used at a total LHSV of $1 \mathrm{~h}^{-1}$.

Practice \#4 aimed to investigate the catalytic performance on the solvent-free HDO by adding $5 \%$ by volume of water into the reaction.

\subsection{Liquid and Gaseous Product Analysis}

Two-phase back pressure regulator was used to reduce a mixed-phase flow streams from high pressure into ambient before they went to a liquid-gas phase separator placed downstream. The liquid products were analysed by gas chromatography-mass spectrometry (GC-MS, Shimadzu GCMS-QP2020, Kyoto, Japan) equipped with a capillary column (DB-1HT, $30 \mathrm{~m} \times 0.32 \mathrm{~mm} \times 0.1 \mu \mathrm{m})$ to inform the quantitative/qualitative data of FFAs, hydrocarbons, and other intermediate products. Detailed information of this method is applied elsewhere [25,26]. Briefly, $10 \mu \mathrm{L}$ of sample was injected into the injection port in a split mode with the inlet temperature of $340{ }^{\circ} \mathrm{C}$. In a GC oven, the oven temperature was kept at $40^{\circ} \mathrm{C}$ for $5 \mathrm{~min}$ then increased to $240^{\circ} \mathrm{C}$ with a rate of $15^{\circ} \mathrm{C} / \mathrm{min}$, then ramped by $8{ }^{\circ} \mathrm{C} / \mathrm{min}$ to $370{ }^{\circ} \mathrm{C}$, which was maintained for another $15 \mathrm{~min}$. The total analysis run time was about $50 \mathrm{~min}$. In the MS zone, the temperatures of ion source and interface were held at $250{ }^{\circ} \mathrm{C}$ during the analysis. The $\mathrm{m} / \mathrm{z}$ was scanned from 2 to 500 . The calibration curves of alkane standards (n- $\mathrm{C}_{8}$ to $n-C_{18}$ ) were used to quantify their weight in the liquid products, and the response factor for isomer products was assumed to be equal to its corresponding n-alkanes. For other oxygenated intermediates, the calculation was referenced by the same type of known standards.

Gas phase was analysed using an online GC equipped with two columns (molecular sieve 5A and Porapak Q), thermal conductivity detector (TCD) and flame ionization detector (FID). The GC was calibrated for all of the gaseous products obtained, including $\mathrm{CO}, \mathrm{CO}_{2}, \mathrm{CH}_{4}, \mathrm{C}_{2} \mathrm{H}_{6}$, and $\mathrm{C}_{3} \mathrm{H}_{8}$.

Feed conversion and product selectivity were calculated based on mass balance. The catalytic performance was evaluated according to oil conversion (Equation (1)), liquid hydrocarbon yield (Equation (2)), selectivity to liquid hydrocarbon product (Equation (3)), and selectivity to gas species (Equation (4)):

Oil conversion $(\%)=(($ mass of oil fed - mass of oil remaining $) /($ mass of oil fed $)) \times 100$,

Liquid hydrocarbon yield $(\%)=($ mass of liquid hydrocarbon produced/mass of oil fed $) \times 100$,

Selectivity to liquid hydrocarbon product $(\%)=$ (mass of each liquid hydrocarbon product/mass of liquid hydrocarbon product in total $) \times 100$,

Selectivity to gas species $(\%)=($ mass of each gas species/mass of gas in total $) \times 100$,

Contribution percentages of the $\mathrm{HDO}$ (Equation (5)) and $\mathrm{DCO} / \mathrm{DCO}_{2}$ (Equation (6)) pathways were calculated based on the total moles of n-alkanes with even numbers or odd numbers of carbon atoms in the liquid product as follows:

$$
\begin{gathered}
\mathrm{HDO}(\%)=\left(\text { mass of } \mathrm{C}_{8}, \mathrm{C}_{10}, \mathrm{C}_{12}, \mathrm{C}_{14}, \mathrm{C}_{16} \text {, and } \mathrm{C}_{18} \text { in product/mass of feed }\right) \times 100, \\
\mathrm{DCO}+\mathrm{DCO}_{2}(\%)=\left(\text { mass of } \mathrm{C}_{9}, \mathrm{C}_{11}, \mathrm{C}_{13}, \mathrm{C}_{15} \text {, and } \mathrm{C}_{17} \text { in product/mass of feed }\right) \times 100
\end{gathered}
$$




\section{Results and Discussion}

\subsection{Catalyst Characterization}

The XRD pattern of NiCo/SAPO-11 (Figure 2a) suggested an alloy formation between Ni and Co, matched with PDF 01-074-5694, in accordance with Huynh and co-workers [27] who prepared bimetallic Ni-Co supported on different acidic materials used in Phenol HDO. Figure 2b,c show porous characteristics of the NiCo/SAPO-11 and SAPO-11 support. The obtained isotherms for all samples could be classified as type IV with hysteresis loops at $0.4<\mathrm{P} / \mathrm{P}_{0}<0.8$ of $\mathrm{H} 4$ type [28]. These results showed that samples possess mesopore structures [29]. High adsorption of $\mathrm{N}_{2}$ appeared in the low relative pressure range, and the hysteresis loops were detected, suggesting the existence of both micropores and mesopores. The pore size distribution plots calculated by DFT method revealed two types of peaks with narrow micropores (high intensity at pore diameter $<2 \mathrm{~nm}$ ) and mesopores (broad peak at pore diameter $\geq 2 \mathrm{~nm}$ ) at approximately 0.98 and $7.78 \mathrm{~nm}$, respectively. Upon NiCo loading, the BET surface area and pore volume of NiCo/SAPO-11 were $\sim 134.4 \mathrm{~m}^{2} / \mathrm{g}$ and $\sim 0.140 \mathrm{~cm}^{3} / \mathrm{g}$, respectively, which were slightly lower than those of pristine SAPO- $11\left(\sim 154.7 \mathrm{~m}^{2} / \mathrm{g}\right.$ and $\sim 0.139 \mathrm{~cm}^{3} / \mathrm{g}$, respectively).

(a)

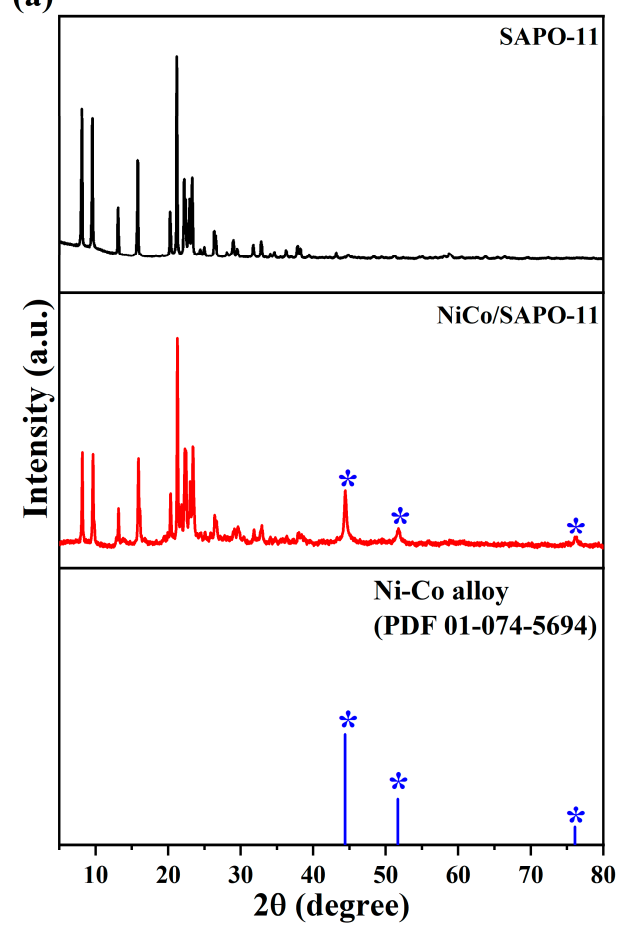

(b)
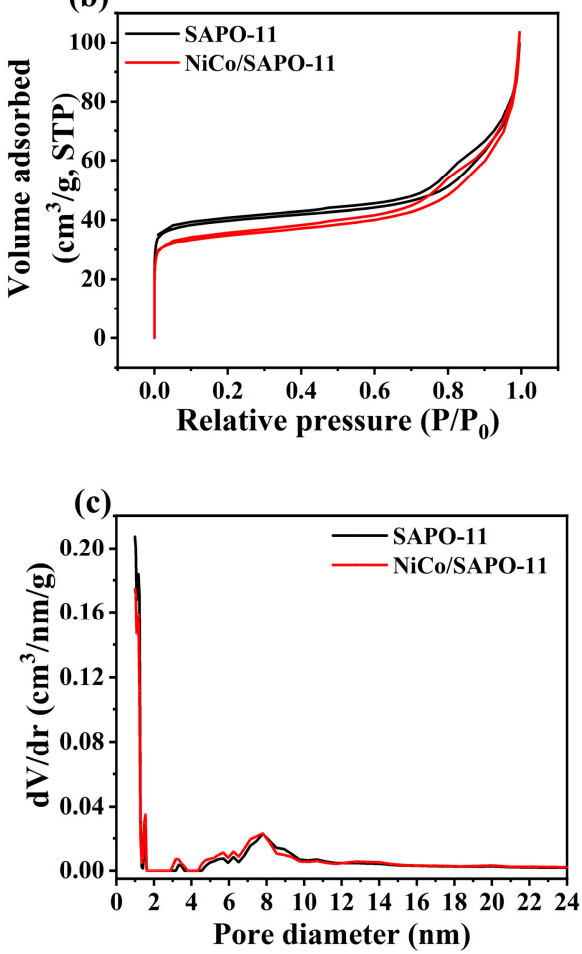

Figure 2. (a) XRD patterns, ${ }^{*} 2 \theta=44.41^{\circ}, 51.78^{\circ}$, and $76.09^{\circ}$ (powder diffraction file (PDF) for Ni-Co alloy (01-074-5694)); (b) $\mathrm{N}_{2}$ adsorption-desorption isotherms; and (c) pore-size distributions of SAPO-11 and the reduced $\mathrm{NiCo} / \mathrm{SAPO}-11$ catalyst.

The SEM image (Figure 3a) indicated that $10 \mathrm{wt} \%$ metal loading does not change the microstructure of SAPO-11 support, which is normally rod-like and has non-smooth surface. The bright field TEM image (Figure $3 b$ ) of the catalyst clearly shows Ni-Co nanoparticles, presented in black spots, in a spherical shape dispersed on the support, presented in the dark grey area. The metal particle size, estimated by measuring at least 100 particles, was about 9-18 nm. This range is consistent with San-Jose-Alonse and co-workers [30], who varied the proportion of Ni:Co. They showed that the particle size of samples prepared by impregnation was $14.1 \mathrm{~nm}$. (for Co), $\sim 8.6 \mathrm{~nm}$. (for NiCo), and $\sim 7.0 \mathrm{~nm}$. (for Ni). It is evidenced by EDS elemental mappings (Figure 3c,d) of the corresponding 
TEM image (Figure 3b) that Ni and Co species appeared at identical areas of the bimetallic particles, possibly due to the alloy structure formation, in good agreement with previous XRD results (Figure 2). Figure 3e,f display the high-resolution TEM (HRTEM) image of a single NiCo nanoparticle and its corresponding EDS line profile, respectively. These results confirm the co-existence of Ni and Co with comparable content of each metal, which was consistent with the analysis result from an inductively coupled plasma-mass spectrometry (ICP-MS) (results not shown). Additionally, lattice spacings of around 1.28 and $2.42 \mathrm{~nm}$ which were rotated by $53^{\circ}$ were evidenced [31]. Evaluated by the $\mathrm{NH}_{3}-\mathrm{TPD}$ technique, total acidity of the SAPO-11 was $0.456 \mathrm{mmol} / \mathrm{g}$, whereas NiCo/SAPO-11 catalyst showed lower values at $0.338 \mathrm{mmol} / \mathrm{g}$ (results not shown), coincided with the lower surface area of the supported catalyst.
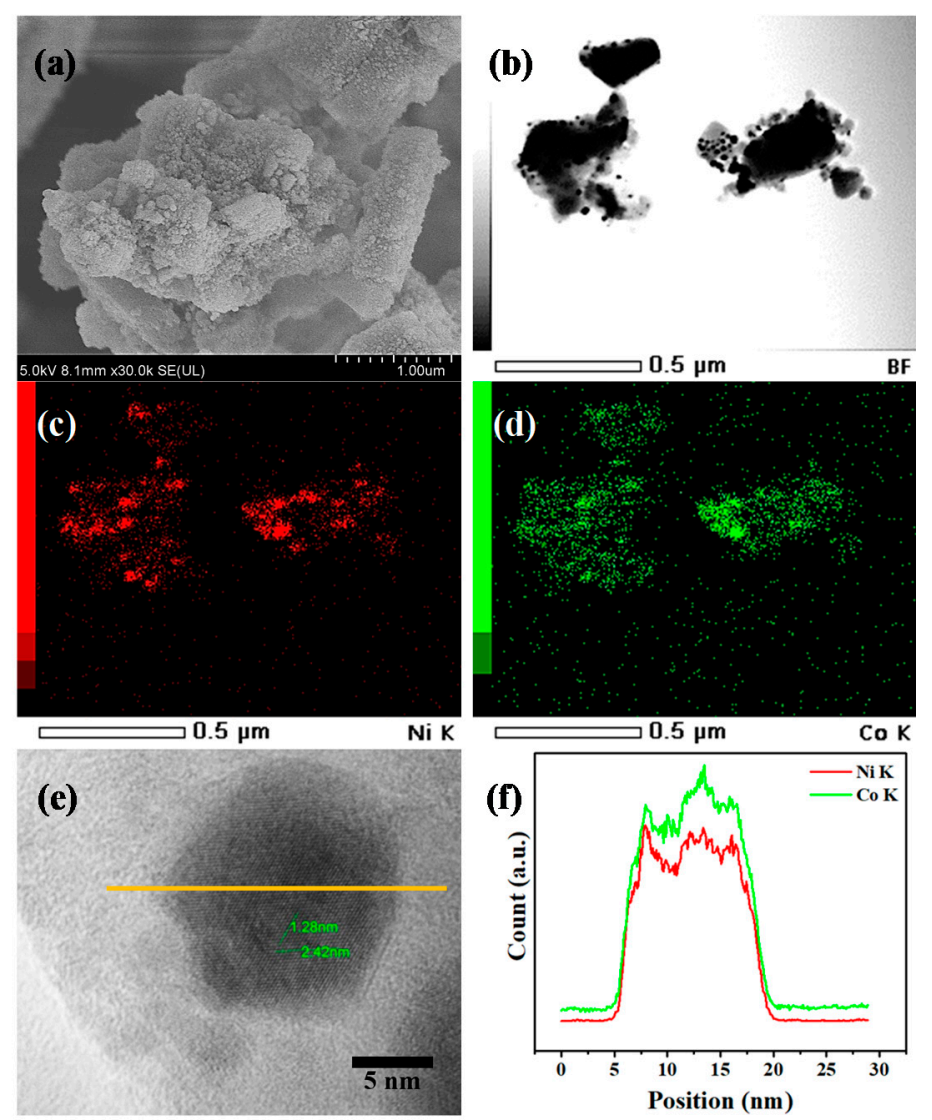

Figure 3. (a) Scanning electron microscopy (SEM) image; (b) transmission electron microscopy (TEM) image; (c,d) corresponding energy dispersive X-ray spectrometer (EDS) elemental mappings of Ni and $\mathrm{Co} ;(\mathbf{e}, \mathbf{f})$ EDS line profile of the NiCo/SAPO-11 catalyst.

\subsection{Feed Compositions}

Table 1 shows fatty acid compositions directly evaluated by GC-MS. It is seen that $\mathrm{C}_{12}$, $\mathrm{C}_{16}$, and $\mathrm{C}_{18}$ fatty acids are major components in coconut oil, with oxygen content $\sim 13 \mathrm{wt} \%$, the ratio of saturated/unsaturated FFAs $\sim 3$ times, which might induce different product distributions. The molecular weights for further calculation were $779.7 \mathrm{~g} / \mathrm{mol}$ for coconut oil. 
Table 1. Fatty acid composition of coconut oil.

\begin{tabular}{cc}
\hline Fatty Acid & Content $\mathbf{( w t} \%)$ \\
\hline Octanoic acid (C8:0) & 0.9 \\
Decanoic acid (C10:0) & 3.3 \\
Dodecanoic acid (C12:0) & 30.1 \\
Myristic acid (C14:0) & 21.5 \\
Palmitic acid (C16:0) & 17.9 \\
Stearic acid (C18:0) & 5.2 \\
Oleic acid (C18:1) & 15.9 \\
Linoleic acid (C18:2) & 4.8 \\
Eicosanoic acid (C20:0) & 0.2 \\
Eicosenoic acid (C20:1) & 0.2 \\
\hline Saturated FFAs & 79.1 \\
Unsaturated FFAs & 20.9 \\
Oxygen & 12.9 \\
\hline
\end{tabular}

\subsection{Hydrogen Production from Glycerol Aqueous-Phase Reforming (Gly-APR) over NiCo/SAPO-11}

As of the complexity during the glycerol-APR process, the reactions of dehydration, dehydrogenation and hydrogenolysis could possibly take place on NiCo/SAPO-11 since the fact that this bifunctional catalyst comprises two main catalytic sites; (1) metal sites prefer to dehydrogenation and (2) acid sites prefer dehydration. Table 2 summarizes the main products such as propylene glycol $\left(\mathrm{C}_{3} \mathrm{H}_{8} \mathrm{O}_{2}\right)$, ethylene glycol $\left(\mathrm{C}_{2} \mathrm{H}_{6} \mathrm{O}_{2}\right)$, acetaldehyde $\left(\mathrm{C}_{2} \mathrm{H}_{4} \mathrm{O}\right)$, 1-propanol, 2-methyl- $\left(\mathrm{C}_{4} \mathrm{H}_{10} \mathrm{O}\right)$, 2-propanone, 1-hydroxy- $\left(\mathrm{C}_{3} \mathrm{H}_{6} \mathrm{O}_{2}\right)$, and ethanol $\left(\mathrm{C}_{2} \mathrm{H}_{5} \mathrm{OH}\right)$ obtained in the condensable phase, which can be confirmed by the fact that side reactions occurred. The most abundant liquid product was ethylene glycol ( 17.8\%), followed by propylene glycol ( 11.0\%), and 2-propanone, 1-hydroxy- ( 10.5\%). In addition, trace amounts of 1-propanol, 2-methyl-, acetaldehyde, and ethanol could be detected $(\sim 7.1 \%)$. These results show a good agreement with the literature in that the same intermediates were reported [32,33]. The comparatively higher selectivity to ethylene glycol indicated that the primary hydroxyl group of glycerol is eliminated by the dehydrogenation pathway. However, the formation of propylene glycol and 2-propanone, 1-hydroxy- indicated that both pathways of the dehydration/hydrogenolysis were presented on Lewis sites of the catalyst. It also points out the high $\mathrm{C}-\mathrm{C}, \mathrm{C}-\mathrm{H}$ cleavage activity of catalyst, accompanied by an increased production of hydrogen. As NiCo/SAPO-11 catalyst was identified to be of weak and medium strength acid sites (i.e., Lewis sites), this would lead to the formation of oxygenated hydrocarbons in the liquid phase (i.e., acetaldehyde, 1-propanol, 2-methyl-, 2-propanone, 1-hydroxy-, and ethanol), suggesting that Lewis sites are involved in $\mathrm{C}-\mathrm{O}$ cleavage. The result also signifies that dehydrogenation, which competes with dehydration/hydrogenolysis, was significantly favoured over bifunctional NiCo/SAPO-11 catalyst.

Table 2. The list of investigated intermediates and their selectivity in liquid product during the glycerol aqueous-phase reforming over $\mathrm{NiCo} / \mathrm{SAPO}-11$ catalyst according to the GC-MS analysis.

\begin{tabular}{|c|c|c|}
\hline Liquid Product & Retention Time (min) & Selectivity (\%) \\
\hline Acetaldehyde & 1.050 & 1.13 \\
\hline Ethanol & 1.259 & 1.97 \\
\hline 1-propanol, 2-methyl- & 4.843 & 30.47 \\
\hline 2-propanone, 1-hydroxy- & 10.585 & 56.75 \\
\hline Propylene glycol & 11.035 & 7.89 \\
\hline Ethylene glycol & 17.858 & 1.80 \\
\hline
\end{tabular}

Reaction conditions: glycerol solution $36 \mathrm{wt} \%$, and $4 \mathrm{~mL}$ catalyst, $230{ }^{\circ} \mathrm{C}, 30$ bar $\mathrm{N}_{2}$. 
Overall, the reaction pathways could be proposed that the reaction involves the $\mathrm{C}-\mathrm{O}$ bond scission, followed by hydrogenation which consumes $\mathrm{H}_{2}$. Therefore, a part of $\mathrm{H}_{2}$ could be consumed and resulted in limited hydrogen production. The formation of ethylene glycol generated from dehydrogenation would support this assumption.

Table 3 shows the main components of the gaseous products: $\mathrm{CH}_{4}>\mathrm{CO}>\mathrm{CO}_{2}>\mathrm{H}_{2}$, respectively. As mentioned above, $\mathrm{H}_{2}$ yield was hardly maintained because $\mathrm{H}_{2}$ was consumed by side reaction (in liquid phase). Notably, the formation of $\mathrm{CH}_{4}$ also confirmed that $\mathrm{H}_{2}$ was used in $\mathrm{CO} / \mathrm{CO}_{2}$ methanation $\left(\mathrm{CO}+3 \mathrm{H}_{2} \leftrightarrow \mathrm{CH}_{4}+\mathrm{H}_{2} \mathrm{O}, \Delta \mathrm{H}_{298}=-206 \mathrm{~kJ} / \mathrm{mol}\right.$ and $\mathrm{CO}_{2}+4 \mathrm{H}_{2} \leftrightarrow \mathrm{CH}_{4}+2 \mathrm{H}_{2} \mathrm{O}$, $\Delta \mathrm{H}_{298}=-164.94 \mathrm{~kJ} / \mathrm{mol}$ ) [33]. Generally, Ni species prefer to generate more CO. However, the amount of $\mathrm{CO}$ formed was higher than that of $\mathrm{CO}_{2}$, suggesting that bimetallic NiCo/SAPO-11 catalyst was favourable to the decomposition of methanol.

Table 3. The yield of gas products during the glycerol aqueous-phase reforming over NiCo/SAPO-11 catalyst according to the GC-MS analysis.

\begin{tabular}{cccc}
\hline Gas Product & Retention Time (min) & Yield $\left(\times \mathbf{1 0}^{-\mathbf{9}} \mathbf{m o l e}\right)$ & Yield $\left(\times \mathbf{1 0}^{-\mathbf{5}} \mathbf{~ m o l} / \mathbf{m o l}\right.$ Glycerol $)$ \\
\hline $\mathrm{H}_{2}$ & 1.78 & 0.0000084 & 0.00000024 \\
$\mathrm{CO}$ & 3.919 & 5.58528 & 1.5926 \\
$\mathrm{CH}_{4}$ & 4.393 & 6.85314 & 1.95412 \\
$\mathrm{CO}_{2}$ & 8.862 & 2.8679 & 0.81775 \\
\hline
\end{tabular}

Reaction conditions: glycerol solution $36 \mathrm{wt} \%$, and $4 \mathrm{~mL}$ catalyst, $230^{\circ} \mathrm{C}, 30$ bar $\mathrm{N}_{2}$.

Co-based catalysts have been reported as less effective materials for the reforming of methanol [34,35]. However, Xue and co-worker [36] promoted Co into $\mathrm{NiCu} / \mathrm{Al}$ catalyst for methanol reforming. The increased $\mathrm{H}_{2}$ amount showed that $\mathrm{Co}$ could promote the reaction by enhancement of water gas shift reaction. Papadopoulou and co-worker [37] investigated the adsorption of methanol on Co-based catalysts. TPD results indicated that the number of active sites provided the catalyst to be able to adsorb or decompose methanol molecules. In Table 3, methanol was not detected among the condensable phase products suggesting the possible reactions of methanol reforming $\left(\mathrm{CH}_{3} \mathrm{OH}+\mathrm{H}_{2} \mathrm{O} \leftrightarrow \mathrm{CO}_{2}+3 \mathrm{H}_{2}\right)$ or methanol decomposition $\left(\mathrm{CH}_{3} \mathrm{OH} \leftrightarrow \mathrm{CO}+2 \mathrm{H}_{2}\right)$ over NiCo/SAPO-11 catalyst. This behaviour coincided with the synergistic effects of Ni-CO alloy in a NiCo/SAPO-11 catalyst in a positive way for $\mathrm{H}_{2}$ production.

\subsection{Catalytic Performance of NiCo/SAPO-11 over In-Situ HDO of Coconut Oil}

Figure 4 displays the results of coconut oil HDO according to the change of co-reactant feed at $330{ }^{\circ} \mathrm{C}, \mathrm{LHSV} 1 \mathrm{~h}^{-1}$, and 50 bar of reaction gas over $4 \mathrm{~mL}$ of NiCo/SAPO-11 catalyst. Under $\mathrm{H}_{2}$ ambient, the catalyst exhibited high activity with $100 \%$ conversion, while more than $85 \%$ of coconut oil conversion could yield the liquid product. Under an inert $\mathrm{N}_{2}$ atmosphere, the conversion was $30 \%$ and liquid product accounted for $15 \%$. With the help of co-reactants, $\mathrm{H}_{2} \mathrm{O}$ and aqueous glycerol, the conversion increased to $70 \%$ and $90 \%$, whereas liquid product yield also increased to $47 \%$ and $87 \%$, respectively. Compared to the conventional $\mathrm{H}_{2}$ ambient, the results verified that the presence of $\mathrm{H}_{2} \mathrm{O}$ and glycerol helped to promote both coconut oil conversion and product yield. In addition, the experimental practices applying $\mathrm{H}_{2}$ below 50 bar (i.e., 30 bar) with and without glycerol solution were also performed. Even though 100\% conversion was also achieved, hydrocarbon liquid yields were dropped to $65-67 \%$, compared with using either 50 bar $\mathrm{H}_{2}$ without glycerol (Practice \#1) or 50 bar $\mathrm{N}_{2}$ with glycerol solution (Practice \#3). This could be because the existence of $\mathrm{H}_{2} \mathrm{O}$ under $\mathrm{H}_{2}$ ambient caused side reaction. Thus, the glycerol did not clearly selective to glycerol reforming. 


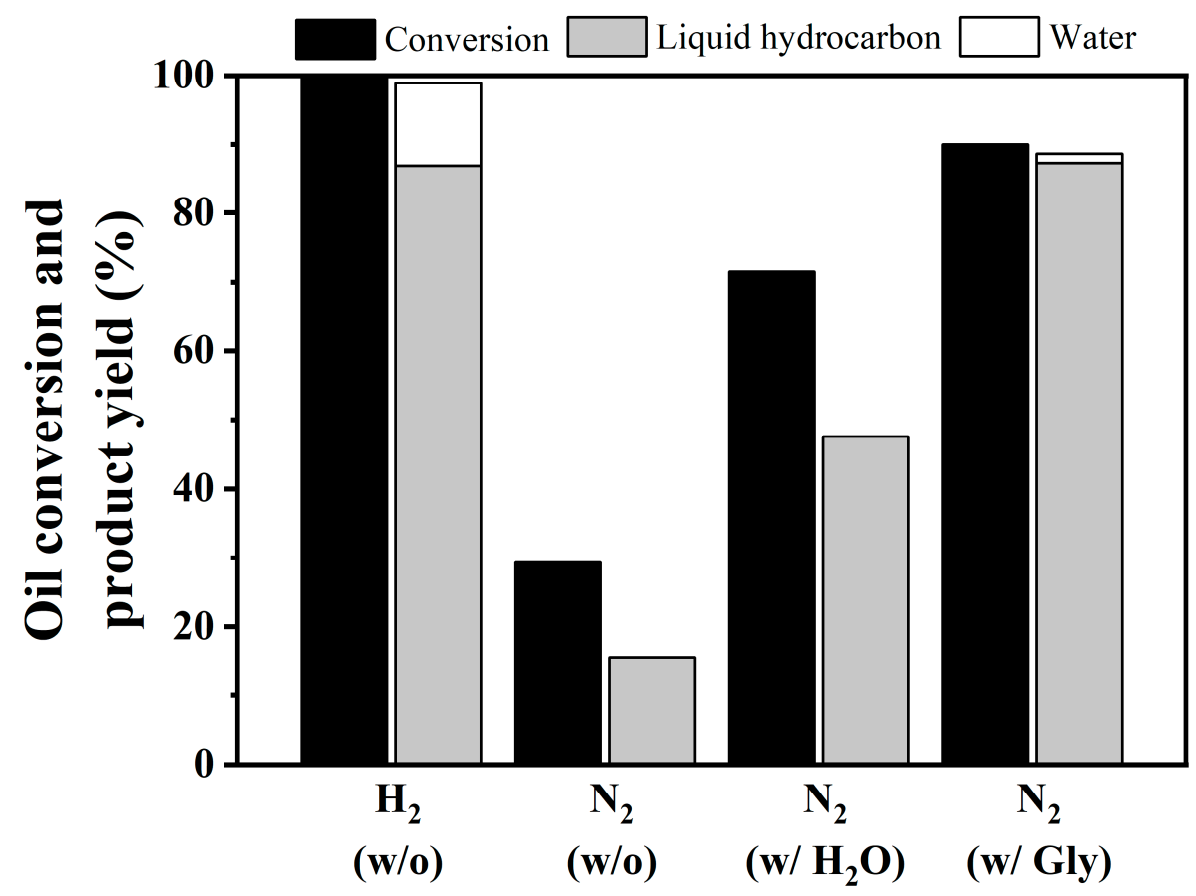

Figure 4. Oil conversion and product yield of coconut oil deoxygenation under different atmospheres with (w/) and without (w/o) co-reactant feeds. (Condition: Coconut oil, LHSV of $1 \mathrm{~h}^{-1}, 330{ }^{\circ} \mathrm{C}$, and 50 bar of reaction gas, Gly = glycerol solution).

Figure 5 shows the liquid product distribution over NiCo/SAPO-11 catalyst. With the help of $\mathrm{H}_{2}$, the catalyst could provide excellent selectivity to alkanes at $97 \%$. Several intermediates (i.e., ketones, aldehydes, alcohols, cycloalkanes esters, FFAs, and alkenes) were detected in the liquid phase, while the $\mathrm{C}_{3} \mathrm{H}_{8}, \mathrm{H}_{2}, \mathrm{CO}$, and $\mathrm{CO}_{2}$ were mainly formed in the gas phase. However, the product distribution was altered (see Figure 6). Under $\mathrm{N}_{2}$ atmosphere, main products are alkanes $\left(\mathrm{C}_{11}-\mathrm{C}_{18}\right)$ and a small amount of FFAs, alkenes, and some alcohols. This finding is consistent with Morgan and co-workers [13], who established the thermal deoxygenation of TGs without $\mathrm{H}_{2}$ over $1 \mathrm{wt} \% \mathrm{Pt} / \mathrm{C}, 5 \mathrm{wt} \% \mathrm{Pd} / \mathrm{C}$, and $20 \mathrm{wt} \%$ $\mathrm{Ni} / \mathrm{C}$ catalysts. However, the existence of fatty acid composition was an important intermediate for alkane formation. Long chains of alkenes and alcohols were produced via hydrocracking. It can be implied that $\mathrm{H}_{2}$ generated from cracking affected the hydrocarbon production [38]. In the presence of $\mathrm{H}_{2} \mathrm{O}, \mathrm{CO}$ and $\mathrm{CO}_{2}$ were mainly formed, while propane was not found in the bulk of gas product (see Figure 6). It can be considered that FFAs are successfully produced by the TG hydrolysis reaction route rather than deoxygenation which requires $\mathrm{H}_{2}$ molecules. However, the produced FFAs will either undergo $\mathrm{DCO}_{2}$ or $\mathrm{DCO}$ without $\mathrm{H}_{2}$ gas.

As also shown in Figure 6, the existence of methane $\left(\mathrm{CH}_{4}\right)$ showed the consumption of $\mathrm{H}_{2}$. As a result, in-situ $\mathrm{H}_{2}$ produced via the water gas shift reaction $\left(\mathrm{CO}+\mathrm{H}_{2} \mathrm{O} \leftrightarrow \mathrm{CO}_{2}+\mathrm{H}_{2}\right.$, $\Delta H_{298}^{0}=-41 \mathrm{~kJ} / \mathrm{mol}$ ) [37] circulated in the system. Interestingly, two major side products were detected: high molecular weight esters or fatty esters (such as dodecanoic acid, dodecyl ester) and acetate compounds (such as octacosyl acetate). The formation of fatty esters might be due to the dehydration reaction of FFAs and alkyl alcohols on acid sites. It is believed that large molecular weight hydrocarbons lead to the deactivation of the catalyst by blocking the catalyst pores and depositing as coke. In addition, with an acidic functionality, acetate can be obtained from dehydrogenation of alcohol couples with aldehyde under an inert atmosphere to yield an acetate [38]. 


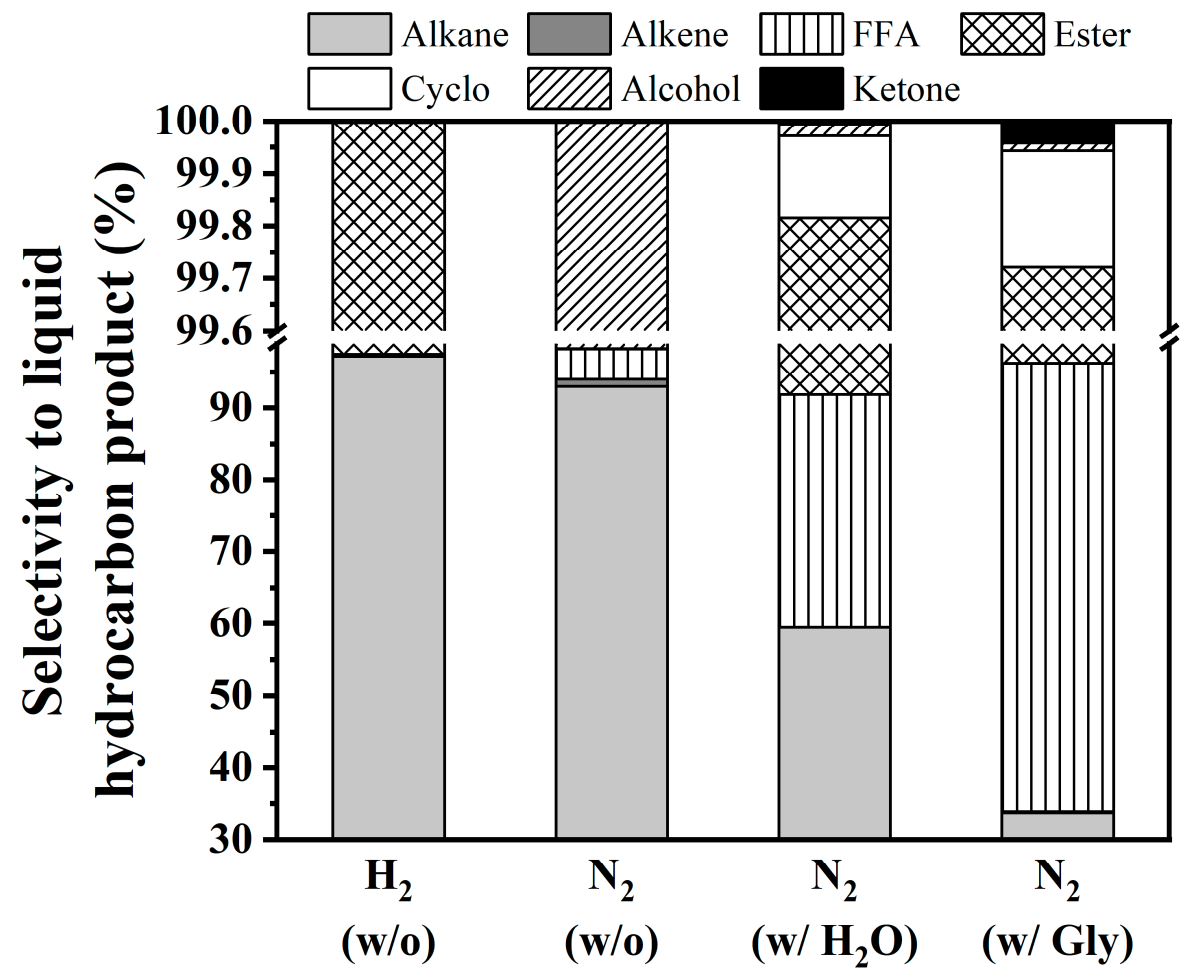

Figure 5. Distribution of liquid hydrocarbon products of coconut oil deoxygenation under different atmospheres with (w/) and without (w/o) co-reactant feeds. (Condition: Coconut oil, LHSV of $1 \mathrm{~h}^{-1}$, $330^{\circ} \mathrm{C}$, and 50 bar of reaction gas, Gly = glycerol solution).

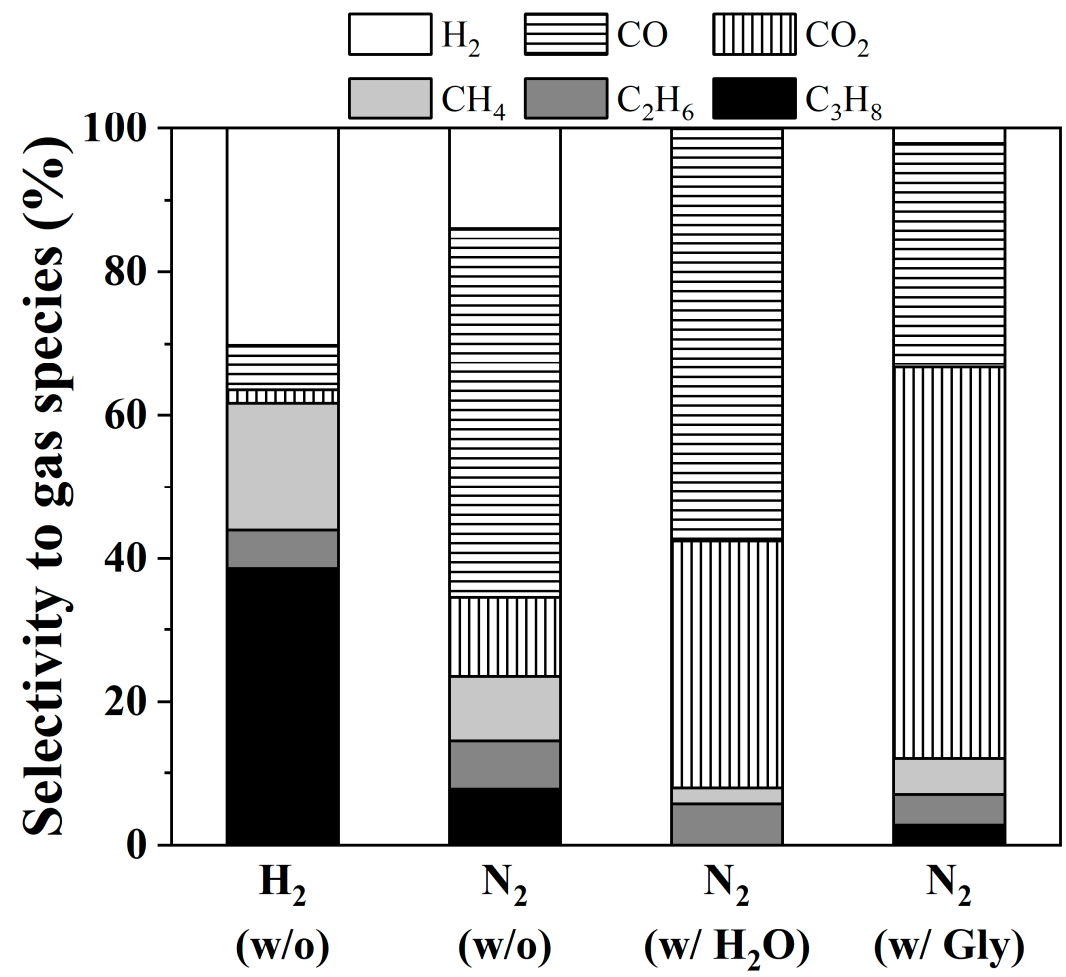

Figure 6. Distribution of gas species of coconut oil deoxygenation under different atmospheres with $(\mathrm{w} /)$ and without (w/o) co-reactant feeds. (Condition: Coconut oil, LHSV of $1 \mathrm{~h}^{-1}, 330^{\circ} \mathrm{C}$, and 50 bar of reaction gas, Gly = glycerol solution). 
In $\mathrm{H}_{2} \mathrm{O}$, the amount of FFAs, originating from hydrolysis of TGs, was much higher. This is in accordance with the literature $[26,39,40]$, in which the disappearing of $\mathrm{C}=\mathrm{O}$ of esters (in the TGs molecules) and the obtaining of $\mathrm{C}=\mathrm{O}$ of carboxylic acids (in the FFAs molecules) in the reaction by using $\mathrm{H}_{2} \mathrm{O}$ were reported. This result confirmed that hydrolysis was the dominant pathway. The presence of $\mathrm{H}_{2} \mathrm{O}$ accelerated and promoted the conversion of TG molecules to FFAs. There was no consumption of hydrogen for the hydrolysis of the TGs. However, the $\mathrm{H}_{2}$ could be further utilized to promote deoxygenation of FFAs ( $\mathrm{DCO}$ or $\mathrm{DCO}_{2}$ ). Therefore, the formation of the desired hydrocarbons was very low. It is known that when there was a lack of $\mathrm{H}_{2}$, which inhibits the catalytic performance, the reaction underwent cracking, for example: $\mathrm{C}_{10} \mathrm{H}_{22} \rightarrow \mathrm{C}_{3} \mathrm{H}_{6}+\mathrm{C}_{7} \mathrm{H}_{16}$. Initially, hydrogen is present in the system because of some hydrocarbon molecules rearranging itself into a cycloalkane or an aromatic hydrocarbon with the loss of $\mathrm{H}_{2}$-for example: $\mathrm{C}_{6} \mathrm{H}_{14} \rightarrow \mathrm{C}_{6} \mathrm{H}_{12}+\mathrm{H}_{2}$-and thus after prolonged reaction times, when this reservoir was consumed, an enhanced formation of aromatic $\mathrm{C}_{\mathrm{n}-1}$ hydrocarbons was observed. Those of FFAs will either undergo $\mathrm{DCO}_{2}$ or DCO. This interesting phenomenon showed that alkenes were formed using either $\mathrm{N}_{2}$ or $\mathrm{H}_{2} \mathrm{O}$. In the latter case, there was enough hydrogen and the formation hydrocarbons was almost constant.

The initial in-situ $\mathrm{H}_{2}$ can be generated from glycerol reforming $\left(\mathrm{C}_{3} \mathrm{H}_{8} \mathrm{O}_{3}+3 \mathrm{H}_{2} \mathrm{O} \leftrightarrow 3 \mathrm{CO}_{2}+7 \mathrm{H}_{2}\right.$, $\left.\Delta H_{298}^{0}=+128 \mathrm{~kJ} / \mathrm{mol}\right)$ [41] and glycerol decomposition $\left(\mathrm{C}_{3} \mathrm{H}_{8} \mathrm{O}_{3} \leftrightarrow 3 \mathrm{CO}+4 \mathrm{H}_{2}, \Delta H_{298}^{0}=+250 \mathrm{~kJ} / \mathrm{mol}\right)[42,43]$. The formation of $\mathrm{H}_{2}, \mathrm{CO}$, and $\mathrm{CO}_{2}$ (Figure 6) confirmed the utilization of glycerol co-feeding to generate in-situ $\mathrm{H}_{2}$. These $\mathrm{H}_{2}$ initially aid the triglyceride breakdown to form propane and FFAs. Unfortunately, the abundant FFAs still remained in the liquid product. It exhibited the insufficiency of in-situ $\mathrm{H}_{2}$ so that alkanes could not be considerably produced. However, this in-situ $\mathrm{H}_{2}$ helps to decrease the level of high molecular weight hydrocarbon compounds.

Table 4 shows the proportion of DCOx/HDO and $\mathrm{CO}_{2} / \mathrm{CO}$. The ratio of DCOx/HDO declined when applying co-reactant as follows: $\mathrm{N}_{2}>$ aqueous glycerol $>\mathrm{H}_{2} \mathrm{O}$. The results indicated that generated $\mathrm{H}_{2}$ had a significant impact on reaction pathways. At the initial of reaction with glycerol co-reactant, an abundance of generated $\mathrm{H}_{2}$ can break $\mathrm{C}-\mathrm{O}$ bonds in TG molecules through the HDO reaction to produce propane and FFAs. However, considering the final gas product, the reaction prefers to promote via $\mathrm{DCO}_{2}$ which does not require $\mathrm{H}_{2}$. It can be said that the rate of breaking of the $\mathrm{C}-\mathrm{O}$ bonds in FFA should be slower than the $\mathrm{C}-\mathrm{O}$ bonds in TGs and $\mathrm{C}-\mathrm{C}$ bonds in FFA itself. On the other hand, the reaction seems to contribute to $\mathrm{DCO}$ when using $\mathrm{H}_{2} \mathrm{O}$ co-reactant. These results indicated that the insufficient $\mathrm{H}_{2}$ at the beginning suppressed HDO. Once FFA was generated, $\mathrm{H}_{2}$ from water gas shift reaction promoted DCO pathway, consistent with other reports [10,14,42-46]. In all conditions, the selectivity to jet fuel range $\left(C_{8}-C_{14}\right)$ was higher than that to diesel fuel range $\left(C_{15}-C_{18}\right)$.

Table 4. Summary reaction pathway and selectivity toward jet and diesel range fuels of the alkane products.

\begin{tabular}{cccccc}
\hline \multirow{2}{*}{ Feed } & \multirow{2}{*}{ Co-Reactant } & \multicolumn{2}{c}{ Selectivity (\%) } & \multirow{2}{*}{ DCO $_{\mathbf{x}} / \mathbf{H D O}^{3}$} & \multirow{2}{*}{$\mathbf{C O}_{2} / \mathrm{CO}$} \\
\cline { 3 - 4 } & & Jet Fuel $^{\mathbf{1}}$ & Diesel Fuel & & \\
\hline \multirow{2}{*}{ Coconut oil } & $\mathrm{H}_{2}$ & 64.09 & 35.91 & 1.08 & 0.30 \\
& $\mathrm{~N}_{2}$ & 28.73 & 71.27 & 2.90 & 0.21 \\
& $\mathrm{H}_{2} \mathrm{O}$ & 62.58 & 37.42 & 1.05 & 0.59 \\
& Glycerol & 58.74 & 41.26 & 1.18 & 1.75 \\
\hline
\end{tabular}

${ }^{1}$ Jet fuel range $=\mathrm{C}_{8}-\mathrm{C}_{14}$ alkanes, ${ }^{2}$ Diesel fuel range $=\mathrm{C}_{15}-\mathrm{C}_{18}$ alkanes, ${ }^{3} \mathrm{DCO}_{\mathrm{x}}=\mathrm{DCO}+\mathrm{DCO}_{2}$.

\section{Conclusions}

The catalytic deoxygenation of coconut oil was performed on NiCo/SAPO-11 nanocatalyst in a continuous-flow reactor for hydrocarbon production. Reaction condition in assistance with in-situ $\mathrm{H}_{2}$ produced from glycerol (50 wt\% aqueous solution), without any external $\mathrm{H}_{2}$ source (under $\mathrm{N}_{2}$ ambient) and addition of $\mathrm{H}_{2} \mathrm{O}$ ( $5 \%$ by volume) was investigated on the deoxygenation reaction and product distribution. The results showed that under $\mathrm{N}_{2}$ atmosphere applying co-reactants $\mathrm{H}_{2} \mathrm{O}$ and glycerol 
significantly increased the oil conversion. The main products were FFAs and their corresponding $\mathrm{C}_{\mathrm{n}-1}$ alkanes, whereas a small fraction of the intermediates was found. Considering FFA products, the addition of $\mathrm{H}_{2} \mathrm{O}$ aids the triglyceride breakdown into FFAs, and the addition of glycerol solution as the hydrogen donor is favourable for the initial hydrogenolysis into FFAs. Then, those FFAs can be either decarbonylated or decarboxylated to their corresponding $\mathrm{C}_{n-1}$ alkanes, in the fraction of jet and diesel fuels. The NiCo/SAPO-11 showed great potential in the production of advanced biofuels in the absence of an external $\mathrm{H}_{2}$ source.

Author Contributions: Conceptualization, K.F., N.L., T.W. and R.K.; formal analysis, R.K. and J.N.; investigation, R.K.; methodology, R.K.; resources, K.F.; supervision, K.F., N.L. and T.W.; writing-original draft, R.K. and J.N.; writing-review and editing, K.F., N.L., R.K., and J.N. All authors have read and agreed to the published version of the manuscript.

Funding: The financial supports from the NANOTEC platform project (P1750381), the CAS-NSTDA project (P1952712), and the Royal Golden Jubilee Ph.D. (RGJ-PHD) Program (Grant No. PHD/0239/2558) are acknowledged.

Conflicts of Interest: The authors declare no conflict of interests.

\section{References}

1. Yeletsky, P.M.; Kukushkin, R.G.; Yakovlev, V.A.; Chen, B.H. Recent advances in one-stage conversion of lipid-based biomass-derived oils into fuel components-aromatics and isomerized alkanes. Fuel 2020, 278, 118255. [CrossRef]

2. The European Parliament; The Council of the European Union. Directive 2009/28/EC of the European Parliament and of the Council of 23 April 2009, on the Promotion of the Use of Energy from Renewable Sources and Amending and Subsequently Repealing Directives 2001/77/EC and 2003/30/EC; The European Parliament: Brussels, Belgium, 2009. Available online: https://eur-lex.europa.eu/eli/dir/2009/30/oj (accessed on 18 November 2020).

3. Abdullah, A.Z.; Razali, N.; Mootabadi, H.; Salamatinia, B. Critical technical areas for future improvement in biodiesel technologies. Environ. Res. Lett. 2007, 2, 34001. [CrossRef]

4. Ogunkunle, O.; Ahmed, N.A. A review of global current scenario of biodiesel adoption and combustion in vehicular diesel engines. Energy Rep. 2019, 5, 1560-1579. [CrossRef]

5. Huang, D.; Zhou, H.; Lin, L. Biodiesel: An alternative to conventional fuel. Energy Procedia 2012, 16, $1874-1885$. [CrossRef]

6. Phumpradit, S.; Reubroycharoen, P.; Kuchonthara, P.; Ngamcharussrivichai, C.; Hinchiranan, N. Partial hydrogenation of palm oil-derived biodiesel over Ni/Electrospun silica fiber catalysts. Catalysts 2020, 10, 993. [CrossRef]

7. Li, X.; Luo, X.; Jin, Y.; OchoaLi, J.; Zhang, H.; Zhang, A.; Xie, J. Heterogeneous sulfur-free hydrodeoxygenation catalysts for selectively upgrading the renewable bio-oils to second generation biofuels. Renew. Sustain. Energy Rev. 2018, 82, 3762-3797. [CrossRef]

8. Kordulis, C.; Bourikas, K.; Gousi, M.; Kordouli, E.; Lycourghiotis, A. Development of nickel based catalysts for the transformation of natural triglycerides and related compounds into green diesel: A critical review. Appl. Catal. B Environ. 2016, 181, 156-196. [CrossRef]

9. Jin, W.; Pastor-Pérez, L.; Villora-Picó, J.J.; Sepúlveda-Escribano, A.; Gu, S.; Reina, T.R. Investigating new routes for biomass upgrading: " $\mathrm{H}_{2}$-free" hydrodeoxygenation using Ni-based catalysts. ACS Sustain. Chem. Eng. 2019, 7, 16041-16049. [CrossRef]

10. Choo, M.-Y.; Juan, J.C.; Oi, L.E.; Ling, T.C.; Ng, E.-P.; Noorsaadah, A.R.; Centi, G.; Lee, K.T. The role of nanosized zeolite $\mathrm{Y}$ in the $\mathrm{H}_{2}$-free catalytic deoxygenation of triolein. Catal. Sci. Technol. 2019, 9, 772-782. [CrossRef]

11. Hollak, S. Catalytic Deoxygenation of Fatty Acids and Triglycerides for Production of Fuels and Chemicals. Ph.D. Thesis, Utrecht University, Utrecht, The Netherlands, 2014.

12. Chiappero, M.; Do, P.T.M.; Crossley, S.; Lobban, L.L.; Resasco, D.E. Direct conversion of triglycerides to olefins and paraffins over noble metal supported catalysts. Fuel 2011, 90, 1155-1165. [CrossRef]

13. Morgan, T.; Grubb, D.; Santillan-Jimenez, E.; Crocker, M. Conversion of triglycerides to hydrocarbons over supported metal catalysts. Top. Catal. 2010, 53, 820-829. [CrossRef] 
14. Miao, C.; Marin-Flores, O.; Davidson, S.D.; Li, T.; Dong, T.; Gao, D.; Wang, Y.; Garcia-Pérez, M.; Chen, S. Hydrothermal catalytic deoxygenation of palmitic acid over nickel catalyst. Fuel 2016, 166, 302-308. [CrossRef]

15. Asikin-Mijan, N.; Lee, H.V.; Juan, J.C.; Noorsaadah, A.R.; Ong, H.C.; Razali, S.M.; Taufiq-Yap, Y.H. Promoting deoxygenation of triglycerides via $\mathrm{Co}-\mathrm{Ca}$ loaded $\mathrm{SiO}_{2}-\mathrm{Al}_{2} \mathrm{O}_{3}$ catalyst. Appl. Catal. Gen. 2018, 552, 38-48. [CrossRef]

16. Cortright, R.D.; Davda, R.R.; Dumesic, J.A. Hydrogen from catalytic reforming of biomass-derived hydrocarbons in liquid water. Nature 2002, 418, 964-967. [CrossRef]

17. Polychronopoulou, K.; Charisiou, N.; Papageridis, K.; Sebastian, V.; Hinder, S.; Dabbawala, A.; AlKhoori, A.; Baker, M.; Goula, M. The effect of Ni addition onto a Cu-based ternary support on the $\mathrm{H}_{2}$ production over glycerol steam reforming reaction. Nanomaterials 2018, 8, 931. [CrossRef]

18. Chen, Z.; Kukushkin, R.G.; Yeletsky, P.M.; Saraev, A.A.; Bulavchenko, O.A.; Millan, M. Coupling hydrogenation of guaiacol with in-situ hydrogen production by glycerol aqueous reforming over $\mathrm{Ni} / \mathrm{Al}_{2} \mathrm{O}_{3}$ and $\mathrm{Ni}-\mathrm{X} / \mathrm{Al}_{2} \mathrm{O}_{3}(\mathrm{X}=\mathrm{Cu}, \mathrm{Mo}, \mathrm{P})$ Catalysts. Nanomaterials 2020, 10, 1420. [CrossRef]

19. Aman, D.; Radwan, D.; Ebaid, M.; Mikhail, S.; van Steen, E. Comparing nickel and cobalt perovskites for steam reforming of glycerol. Mol. Catal. 2018, 452, 60-67. [CrossRef]

20. Li, K.T.; Yen, R.H. Aqueous-phase hydrogenolysis of glycerol over Re promoted Ru catalysts encapuslated in porous silica nanoparticles. Nanomaterials 2018, 8, 153. [CrossRef]

21. Zhong, H.; Yao, G.; Cui, X.; Yan, P.; Wang, X.; Jin, F. Selective conversion of carbon dioxide into methane with a 98\% yield on an in-situ formed Ni nanoparticle catalyst in water. Chem. Eng. J. 2019, 357, 421-427. [CrossRef]

22. Hu, X.; Li, P.; Zhang, X.; Yu, B.; Lv, C.; Zeng, N.; Luo, J.; Zhang, Z.; Song, J.; Liu, Y. Ni-based catalyst derived from $\mathrm{NiAl}$ layered double hydroxide for vapor phase catalytic exchange between hydrogen and water. Nanomaterials 2019, 9, 1688. [CrossRef]

23. Ma, Z.; Liu, Z.; Song, H.; Bai, P.; Xing, W.; Yan, Z.; Zhao, L.; Zhang, Z.; Gao, X. Synthesis of hierarchical SAPO-11 for hydroisomerization reaction in refinery processes. Appl. Petrochem. Res. 2014, 4, 351-358. [CrossRef]

24. Zuo, H.; Liu, Q.; Wang, T.; Ma, L.; Zhang, Q.; Zhang, Q. Hydrodeoxygenation of methyl palmitate over supported Ni catalysts for diesel-like fuel production. Energy Fuels 2012, 26, 3747-3755. [CrossRef]

25. Srifa, A.; Faungnawakij, K.; Itthibenchapong, V.; Assabumrungrat, S. Roles of monometallic catalysts in hydrodeoxygenation of palm oil to green diesel. Chem. Eng. J. 2015, 278, 249-258. [CrossRef]

26. Kaewmeesri, R.; Srifa, A.; Itthibenchapong, V.; Faungnawakij, K. Deoxygenation of waste chicken fats to green diesel over $\mathrm{Ni} / \mathrm{Al}_{2} \mathrm{O}_{3}$ : Effect of water and free fatty acid content. Energy Fuels 2015, 29, 833-840. [CrossRef]

27. Huynh, T.M.; Armbruster, U.; Phan, B.M.Q.; Nguyen, D.A.; Martin, A. The influence of cobalt in bimetallic $\mathrm{Ni}-\mathrm{Co}$ catalyst supported on H-Beta for phenol hydrodeoxygenation. Chim. Oggi. Chem. Today 2014, $32,40-44$.

28. Sotomayor, F.J.; Cychosz, K.A.; Thommes, M. Characterization of micro/mesoporous materials by physisorption: Concepts and case studies. Acc. Mater. Surf. Res. 2018, 3, 36-37.

29. Said, S.; Zaky, M.T. Pt/SAPO-11 catalysts: Effect of platinum loading method on the hydroisomerization of n-hexadecane. Catal. Lett. 2019, 149, 2119-2131. [CrossRef]

30. San-José-Alonso, D.; Juan-Juan, J.; Illán-Gómez, M.J.; Román-Martínez, M.C. Ni, Co and bimetallic Ni-Co catalysts for the dry reforming of methane. Appl. Catal. A Gen. 2009, 371, 54-59. [CrossRef]

31. Gao, X.; Tan, Z.; Hidajat, K.; Kawi, S. Highly reactive $\mathrm{Ni}-\mathrm{Co} / \mathrm{SiO}_{2}$ bimetallic catalyst via complexation with oleylamine/oleic acid organic pair for dry reforming of methane. Catal. Today 2017, 281, 250-258. [CrossRef]

32. Reynoso, A.J.; Iriarte-Velasco, U.; Gutiérrez-Ortiz, M.A.; Ayastuy, J.L. Highly stable $\mathrm{Pt} / \mathrm{CoAl}_{2} \mathrm{O}_{4}$ catalysts in aqueous-phase reforming of glycerol. Catal. Today 2020, in press. [CrossRef]

33. Reynoso, A.J.; Ayastuy, J.L.; Iriarte-Velasco, U.; Gutiérrez-Ortiz, M.A. Cobalt aluminate spinel-derived catalysts for glycerol aqueous phase reforming. Appl. Catal. B Environ. 2018, 239, 86-101. [CrossRef]

34. Wei, Y.; Li, S.; Jing, J. Synthesis of Cu-Co catalysts for methanol decomposition to hydrogen production via deposition-precipitation with urea method. Catal. Lett. 2019, 149, 2671-2682. [CrossRef]

35. Wang, L.; Guan, E.; Wang, Y. Silica accelerates the selective hydrogenation of $\mathrm{CO}_{2}$ to methanol on cobalt catalysts. Nat. Commun. 2020, 11, 1-9. [CrossRef] [PubMed] 
36. Xue, H.; Xu, J.; Gong, X.; Hu, R. Performance of a Ni-Cu-Co/ $\mathrm{Al}_{2} \mathrm{O}_{3}$ catalyst on in-situ hydrodeoxygenation of bio-derived phenol. Catalysts 2019, 9, 952. [CrossRef]

37. Papadopoulou, E.; Ioannides, T. Methanol reforming over cobalt catalysts prepared from fumarate precursors: TPD investigation. Catalysts 2016, 6, 33. [CrossRef]

38. Krobkrong, N.; Itthibenchapong, V.; Khongpracha, P.; Faungnawakij, K. Deoxygenation of oleic acid under an inert atmosphere using molybdenum oxide-based catalysts. Energy Convers. Manag. 2018, 167, 1-8. [CrossRef]

39. Authayanun, S.; Arpornwichanop, A.; Paengjuntuek, W.; Assabumrungrat, S. Thermodynamic study of hydrogen production from crude glycerol autothermal reforming for fuel cell applications. Int. J. Hydrogen Energy 2010, 35, 6617-6623. [CrossRef]

40. Li, Y.; Zhang, C.; Liu, Y.; Tang, S.; Chen, G.; Zhang, R.; Tang, X. Coke formation on the surface of Ni/HZSM-5 and Ni-Cu/HZSM-5 catalysts during bio-oil hydrodeoxygenation. Fuel 2017, 189, 23-31. [CrossRef]

41. Gosselink, R.W.; Hollak, S.A.; Chang, S.W.; van Haveren, J.; de Jong, K.P.; Bitter, J.H.; van Es, D.S. Reaction pathways for the deoxygenation of vegetable oils and related model compounds. ChemSusChem 2013, 6, 1576-1594. [CrossRef]

42. Avasthi, K.S.; Reddy, R.N.; Patel, S. Challenges in the production of hydrogen from glycerol-A biodiesel byproduct via steam reforming process. Procedia Eng. 2013, 51, 423-429. [CrossRef]

43. Wang, M.; Wang, Z.; Gong, X.; Guo, Z. The intensification technologies to water electrolysis for hydrogen production-A review. Renew. Sustain. Energy Rev. 2014, 29, 573-588. [CrossRef]

44. Hollak, S.A.; Ariëns, M.A.; de Jong, K.P.; van Es, D.S. Hydrothermal deoxygenation of triglycerides over Pd/C aided by in-situ hydrogen production from glycerol reforming. ChemSusChem 2014, 7, 1057-1062. [CrossRef]

45. Hu, W.; Wang, H.; Lin, H.; Zheng, Y.; Ng, S.; Shi, M.; Zhao, Y.; Xu, R. Catalytic decomposition of oleic acid to fuels and chemicals: Roles of catalyst acidity and basicity on product distribution and reaction pathways. Catalysts 2019, 9, 1063. [CrossRef]

46. Sousa, F.P.; Silva, L.N.; de Rezende, D.B.; de Oliveira, L.C.A.; Pasa, V.M.D. Simultaneous deoxygenation, cracking and isomerization of palm kernel oil and palm olein over beta zeolite to produce biogasoline, green diesel and biojet-fuel. Fuel 2018, 223, 149-156. [CrossRef]

Publisher's Note: MDPI stays neutral with regard to jurisdictional claims in published maps and institutional affiliations.

(C) 2020 by the authors. Licensee MDPI, Basel, Switzerland. This article is an open access article distributed under the terms and conditions of the Creative Commons Attribution (CC BY) license (http://creativecommons.org/licenses/by/4.0/). 